\title{
Optical Rotatory Dispersion and Circular Dichroism of
} Amino Acid Hydantoins

\author{
Tateo Suzuki, Keiji Igarashi, Kieko Hase \\ and Katura Tuzimura \\ Laboratory of Analytical Chemistry, Department of Food Chemistry, Faculty of Agriculture, \\ Tohoku University, Tsutsumidori-Amamiyamachi, Sendai
}

Received September 11, 1972

\begin{abstract}
Optical rotatory dispersion (ORD) and circular dichroism (CD) of 17 amino acid hydantoins were measured between 190 and $600 \mathrm{~nm}$. Most of hydantoins exhibited the negative Cotton effect which showed the trough between 238 and $245 \mathrm{~nm}$. The negative trough of CD was also observed between 212 and $236 \mathrm{~nm}$. The Cotton effect of hydantoins was attributable to $n \rightarrow \pi^{*}$ transition of carbonyl group at $\mathrm{C}-4$ of hydantoin ring.
\end{abstract}

Amino acid hydantoins are prepared with urea or potassium cyanate followed by the acidification with hydrochloric acid. The potassium cyanate method maintains the optical activity of hydantoin, whereas the urea method proceeds with loss of activity. Neuberger ${ }^{1 /}$ mentioned that the hydantoins derived from L-amino acids showed the negative molecular rotations at sodium $\mathrm{D}$-line $(589 \mathrm{~nm})$, and that the derivatives were available to the stereochemistry of amino acids.

Stark $^{2)}$ reported the application of hydantoin for the amino termini determination of peptide.

In this paper, ORD and $C D$ or hydantoins are described.

\section{EXPERIMENT}

\section{Preparation of the sample}

Representative procedures were as follows.

1. Preparation of 5-methylhydantoin (hydantoin derived from alanine). L-Alanine $4.5 \mathrm{~g}$ (0.05 mole) and $4.9 \mathrm{~g}$ of potassium cyanate were dissolved in $30 \mathrm{ml}$ water and were allowed to react for $30 \mathrm{~min}$ at $70^{\circ} \mathrm{C}$ with stirring. The reaction mixture was refluxed with $30 \mathrm{ml}$ of $6 \mathrm{~N}$ hydrochloric acid. After filtration, the solution was allowed to stand overnight in a refrigerator. Recrystallization from hot water gave $4.5 \mathrm{~g}$ of the hydantoin in $79.0 \%$ yield.

2. Preparation of 5-isobutylhydantoin (hydantoin derived from leucine). L-Leucine $6.6 \mathrm{~g} \quad(0.05$ mole $)$ and $4.9 \mathrm{~g}$ of potassium cyanate were dissolved and suspended in $30 \mathrm{ml}$ of water. Pyridine (ca. $25 \mathrm{ml}$ ) was added to dissolve the amino acid. The solution was allowed to react for $1 \mathrm{hr}$ at $60^{\circ} \mathrm{C}$ with stirring. Pyridine was extracted with $300 \mathrm{ml}$ of ethylacetate. The aqueous layer was refluxed for $30 \mathrm{~min}$ by the addition of $30 \mathrm{ml}$ of $6 \mathrm{~N}$ hydrochloric acid and $30 \mathrm{ml}$ of glacial acetic acid. The solution was allowed to stand overnight in a refrigerator. Recrystallization from hot ethanol-water or hot ethanol gave $5.8 \mathrm{~g}$ of the hydantoin in $74.3 \%$ yield.

According to the procedure-1,12 hydantoins were prepared, including the derivatives of alanine, phenylalanine, aspartic acid, glutamic acid, lysine, arginine, histidine, methionine, cysteine, proline, serine and threonine. Histidine hydantoin was obtained by the adjustment of $\mathrm{pH}$ to 5 with $2 \mathrm{~N}$ sodium hydroxide after cyclization. Arginine hydantoin was prepared according to the Boon and Robson. ${ }^{3)}$ Lysine, which has $\varepsilon$-amino group, reacted with double the molar quantity of potassium cyanate, as a similar manner of phenylisothiocyanate. Reaction of other functional groups was in a similar manner of phenylthiohydantoin with the exception of serine and threonine.

Five hydantoins were prepared according to the procedure- 2 , including the derivatives of valine, leucine, isoleucine, tyrosine and tryptophan. Pyridine and acetic acid were added to dissolve the amino acid.

The hydantoins from glycine, asparagine and glutamine were not prepared, since glycine has no asymmetric carbon, and asparagine and glutamine were hydrolized to aspartic acid and glutamic acid respectively.

The all 17 hydantoins were checked by thin-layer chromatography (developer; n-butanol: acetic acid: water $=4: 1: 2$ or $3: 1: 1$ ). They were confirmed to be one spot on each chromatogram, except threonine hydantoin (which is discussed later), both by the 
detection with ninhydrin and tert-butylhypochlorite.

Equipments and operation of spectroscopy

a. Infra-red spectroscopy. Japan Spectroscopic Co., JASCO model IR-S. Samples were measured on $\mathrm{KBr}$ disk. Spectra were calibrated with polystyrene film.

b. Nuclear magnetic resonance spectroscopy (NMR). Varian T-60. Samples ( $\mathrm{ca} .30 \mathrm{mg}$ ) were dissolved in about $0.3 \mathrm{ml}$ of $\mathrm{d}_{6}$-DMSO. Tetramethylsilane was used as the internal standard.

c. ORD and $C D$. JASCO model ORD/UV-5. Samples (ca. $100 \mathrm{mg}$ ) were weighed exactly and dissolved. ORD and CD were measured with $1 \mathrm{~mm}$ cell after the proper dilution by ethanol or water. Molecular rotations at $589 \mathrm{~nm}$ were measured with $10 \mathrm{~mm}$ cell. Region near $230 \mathrm{~nm}$ was also measured with $0.1 \mathrm{~mm}$ cell.

\section{RESULTS AND DISCUSSION}

1. Preparation of hydantoin-Especially serine and threonine hydantoin-

Melting points and elementary analysis were showed in Table I. Infra-red spectrum of leucine hydantoin showed in Fig. 1 as the representative. Peaks near $1770 \mathrm{~cm}^{-1}$ and $1730 \mathrm{~cm}^{-1}$ were attributable to the carbonyl groups at C-2 (ureido form) and at C-4 (amideform) respectively (Table II).
TABLE II. INFRA-RED ABSORPTION $\left(\mathrm{cm}^{-1}\right)$ OF Carbonyl Groups of Hydantorns

\begin{tabular}{lll}
\hline Ala & 1720 & 1740 \\
Val & 1720 & 1760 \\
Leu & 1730 & 1770 \\
Ile & $1700 \sim 1740$ (broad) & \\
Asp & 1680 & 1770 \\
Glu & $1630 \sim 1750$ (broad) & \\
Phe & 1730 & 1770 \\
Tyr & $1690 \sim 1740$ (broad) & \\
Try & $1710 \sim 1725$ (broad) & 1770 \\
Met & 1730 & 1770 \\
CySO ${ }_{3} \mathrm{H}$ & $1690 \sim 1720$ (broad) & 1760 \\
Ser & $1690 \sim 1760$ (broad) & \\
Thr & $1690 \sim 1760$ (broad) & \\
Lys & $1700 \sim 1725$ (broad) & 1750 \\
Arg & 1720 & 1760 \\
His & 1725 & 1760 \\
Pro & $1695 \sim 1760$ (broad) & \\
\hline
\end{tabular}

In the case of thiohydantoins from serine and threonine (for example, phenylthiohydantoin), hydroxyl group is dehydrated and polymerized during cyclization, resulting colored compounds. Serine and threonine hydantoins were, however, scarcely dehydrated which were supported by elementary analysis and NMR. Especially, serine hydantoin seemed to be more stable than threonine hydantoin.

Table I. Elementary Analysis and Mp of Hydantoins

\begin{tabular}{|c|c|c|c|c|c|c|c|c|}
\hline \multirow{2}{*}{ Compd. } & \multirow{2}{*}{$\begin{array}{c}\operatorname{mp}\left({ }^{\circ} \mathrm{C}\right) \\
\text { (lit.) }\end{array}$} & \multicolumn{3}{|c|}{ Calculated $(\%)$} & \multirow{2}{*}{$\begin{array}{c}\operatorname{mp}\left({ }^{\circ} \mathrm{C}\right) \\
(\exp .)\end{array}$} & \multicolumn{3}{|c|}{ Found $(\%)$} \\
\hline & & $\mathrm{C}$ & $\mathrm{H}$ & $\mathbf{N}$ & & $\mathrm{C}$ & $\mathrm{H}$ & $\mathrm{N}$ \\
\hline $\mathrm{Ala}^{-}$ & $174 \sim 7$ & 42.10 & 5.30 & 24.55 & 177 & 41.72 & 5.31 & 24.47 \\
\hline Val & $146 \sim 8$ & 50.69 & 7.07 & 19.71 & 145 & 50.45 & 7.02 & 19.43 \\
\hline Leu & $212 \sim 4$ & 53.83 & 7.74 & 17.94 & 214 & 53.63 & 7.77 & 18.24 \\
\hline Ile & $150 \sim 1$ & 53.83 & 7.74 & 17.94 & 148 & 53.83 & 7.67 & 18.04 \\
\hline Asp & $210 \sim 3$ & 37.98 & 3.83 & 17.72 & 218 & 37.67 & 3.64 & 18.01 \\
\hline Glu & $175 \sim 6$ & 41.86 & 4.68 & 16.28 & 174 & 41.70 & 4.58 & 16.17 \\
\hline Phe & $181 \sim 3$ & 63.15 & 5.30 & 14.73 & 182 & 63.35 & 5.13 & 15.00 \\
\hline Tyr & $261 \sim 4$ & 58.25 & 4.89 & 13.58 & 262 & 58.10 & 4.82 & 13.50 \\
\hline Try & $248 \sim 51$ & 62.87 & 4.84 & 18.33 & 244 & 62.64 & 4.69 & 18.41 \\
\hline Met & $103 \sim 5$ & 41.36 & 5.79 & 16.08 & 104 & 41.23 & 5.65 & 16.40 \\
\hline $\mathrm{CySO}{ }_{3} \mathrm{H}$ & - & 20.83 & 3.06 & 12.15 & $273 d$ & 20.54 & 2.11 & 12.24 \\
\hline Ser & $187 \sim 8$ & 36.93 & 4.65 & 21.53 & 188 & 36.61 & 4.49 & 21.54 \\
\hline Thr & $193 \sim 6$ & 41.66 & 5.59 & 19.44 & 200 & 41.87 & 5.34 & 19.33 \\
\hline Lys & $195 \sim 7$ & 44.85 & 6.59 & 26.16 & 193 & 44.85 & 6.64 & 26.15 \\
\hline Arg & 100 & 34.36 & 6.18 & 28.62 & 100 & 34.30 & 6.04 & 28.45 \\
\hline His & 235 & 28.81 & 4.19 & 25.86 & $280<$ & 28.99 & 4.14 & 25.78 \\
\hline Pro & $163 \sim 5$ & 51.42 & 5.75 & 19.99 & 165 & 49.22 & 5.61 & 19.81 \\
\hline
\end{tabular}




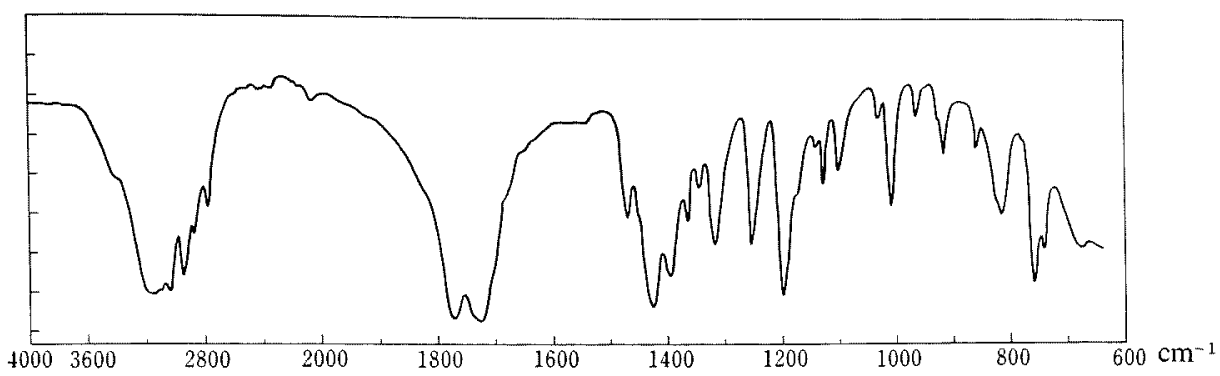

Fig. 1. Infra-red Spectrum of Leucine Hydantoin. 5-isobutylhydantoin
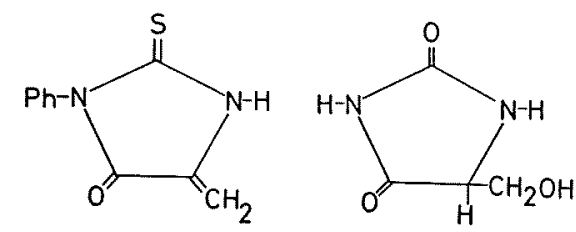

Phenylthiohydantoin

Serine derivatives

In NMR of serine hydantoin, protons of imino groups at $\mathrm{N}-1$ and $\mathrm{N}-3$ showed $\delta=7.87$ and 11.70 respectively. These peaks disappeared by the dilution with deuterium oxide. Proton of hydroxyl group, though not clear, appeared at $3.5 \sim 4.3$. The triplet at 4.03 and doublet at 3.58 were cccounted for a proton attached at asymmetric carbon-5 and two protons at $\beta$-carbon respectively $(J=3.0 \mathrm{cps})$. Temperature was elevated to $60^{\circ} \mathrm{C}$ in order to shift the peak which was attributable to water.

In NMR of threonine hydantoin, protons attached to asymmetric carbon-5 and $\beta$ carbon appeared at $3.8 \sim 4.2$ and two imino protons attached to $\mathrm{N}-1$ and $\mathrm{N}-3$ appeared at 7.86 and 10.53 respectively. Protons of hydroxyl and methyl group appeared at 4.87 and 1.15 respectively. In the case of threonine hydantoin, small amount of dehydration proceeds simultaneously. Methine and methyl group of dehydrated threonine hydantoin showed at 5.60 (quartet) and 1.76 (doublet) $(J=7.5 \mathrm{cps})$ respectively.

\section{2. $O R D$ and $C D$.}

Molecular rotations of 17 hydantoins had usually larger magnitude than those of phenylthiohydantoins ${ }^{4)}$ and methylthiohydantoins. ${ }^{5 \text { ) }}$<smiles>CC=C1NC(=O)NC1=O</smiles>

Dehydrated threonine hydantoin

The found magnitude of molecular rotation, however, was not constant, because of tautomerization which has been studied with ultraviolet spectra ${ }^{5)}$ and with several kinds of peptide derivatives. $^{7}$ Found molecular rotations at $589 \mathrm{~nm}$ of prepared hydantoins were smaller than those in the literature ${ }^{1 \text { ( }}$ (Table III).

Thirteen hydantoins, including the derivatives of alanine, valine, leucine, isoleucine, phenylalanine, serine, threonine, aspartic acid,

Table III. " $[\alpha]_{D}$ " of Hydantorns

\begin{tabular}{|c|c|c|c|c|c|}
\hline \multirow{3}{*}{$\overline{\text { Ala }}$} & \multirow{4}{*}{$\begin{array}{l}-48^{\circ} \\
-134\end{array}$} & \multirow{3}{*}{$\begin{array}{l}\begin{array}{l}\text { Found } \\
\text { Temp. }\end{array} \\
28^{\circ} \mathrm{C}\end{array}$} & \multicolumn{3}{|c|}{ Literature ${ }^{1\}}$} \\
\hline & & & \multirow{2}{*}{$\frac{\text { Solv. }}{E}$} & \multicolumn{2}{|c|}{ Solv. } \\
\hline & & & & $-58^{\circ} \mathrm{C}$ & $\mathrm{CW}$ \\
\hline Val & & 28 & $\mathrm{E}$ & & \\
\hline Leu & -94 & 28 & $\mathrm{E}$ & -148 & $50 \%-\mathrm{E}$ \\
\hline Ile & -99 & 28 & $\mathrm{E}$ & & \\
\hline Asp & -150 & 24 & W & -198 & $1 \mathrm{~N} \mathrm{NaOH}$ \\
\hline Glu & -119 & 26 & W & -136 & $1 \mathrm{~N} \mathrm{NaOH}$ \\
\hline Phe & -182 & 24 & $\mathrm{E}$ & -183 & $50 \%-\mathrm{E}$ \\
\hline Tyr & -165 & 23 & $\mathrm{E}$ & -292 & $1 \mathrm{~N} \mathrm{NaOH}$ \\
\hline Try & -161 & 28 & $\mathrm{E}$ & & \\
\hline Met & -62 & 28 & $\mathrm{E}$ & & \\
\hline $\mathrm{CySO}_{3} \mathrm{H}$ & 0 & 24 & W & & \\
\hline Ser & -281 & 28 & $\mathrm{E}$ & & \\
\hline Thr & -168 & 26 & $\mathrm{E}$ & & \\
\hline Lys & -118 & 28 & W & & \\
\hline Agr & -101 & 28 & W & & \\
\hline His & -10 & 24 & W & & \\
\hline Pro & -169 & 28 & $\mathrm{E}$ & -334 & W \\
\hline
\end{tabular}

solvent: $\mathrm{E}$; ethanol, W; water. 


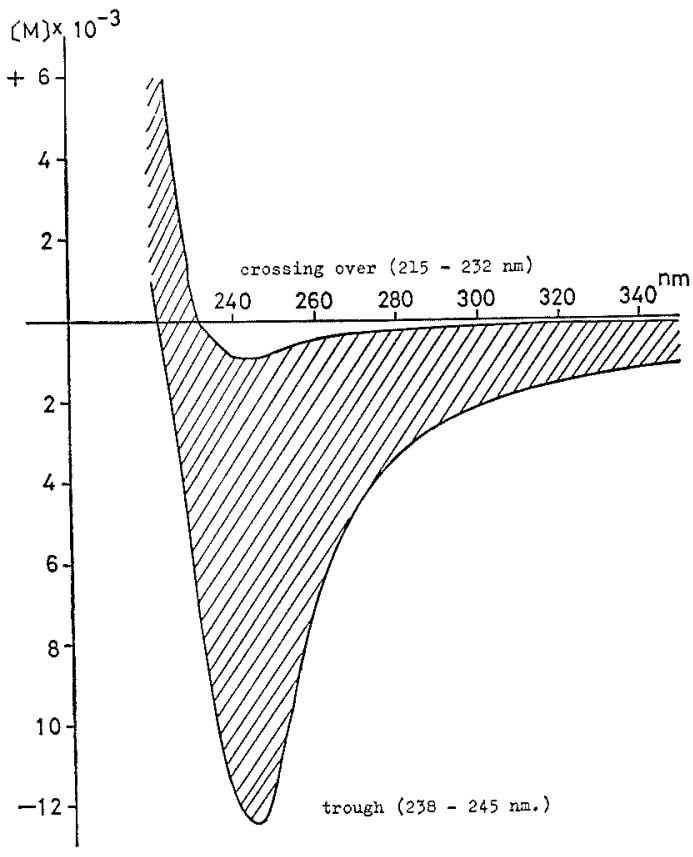

FIG. 2, ORD Curves of Hydantoins.

Alanine, valine, leucine, isoleucine, aspartic acid, glutamic acid, methionine, phenylalanine, lysine, arginine, histidine, serine and threonine.

glutamic acid, lysine, arginine, histidine and methionine, showed the negative Cotton effect between 238 and $245 \mathrm{~nm}$ (Fig. 2). The Cotton effect revealed between 240 and $244 \mathrm{~nm}$ in ethanol. The Cotton effect shifted by solvent effect in water. Dispersion curves crossed over the base line which agreed theoretically with the minimum wave length of CD. The peak of ORD were notmeasurable, even by $0.1 \mathrm{~mm}$ cell, because of the disturbance of the strong ultraviolet absorption below $220 \mathrm{~nm}$, mainly ring absorption.

Three hydantoins, including tyrosine, tryptophan and proline, showed the characteristic curves (Fig. 3).

Tyrosine hydantoin showed the negative Cotton effect at $248 \mathrm{~nm}$. The trough of CD was observed at $234 \mathrm{~nm}$ and the peak was at $207 \mathrm{~nm}$. Measurement between 270 and 300 $\mathrm{nm}$, however, was not clear. It likely showed an additional Cotton effect in the range of absorption band of the aromatic group.

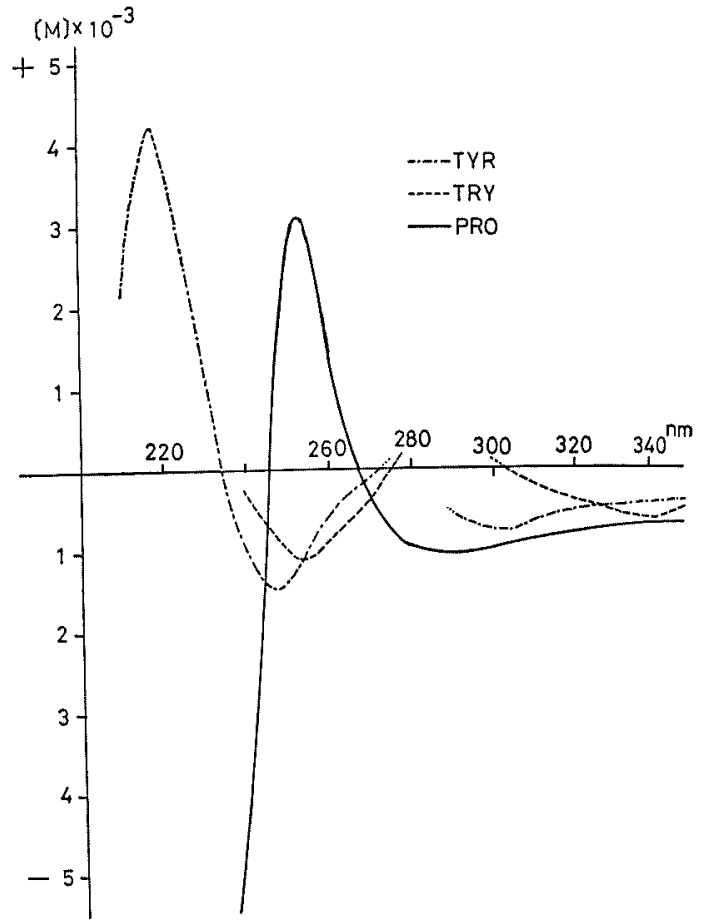

FIG. 3. ORD Curves of Hydantoins.

Tyrosine, proline and tryptophan.

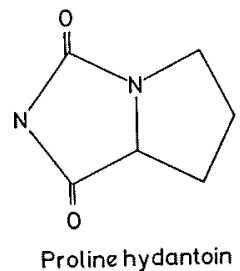

Tryptophan hydantoin showed the negative Cotton effect which had the trough at $256 \mathrm{~nm}$. Measurement was not clear between 260 and $290 \mathrm{~nm}$. The CD peak and trough were observed at $274 \mathrm{~nm}$ and $240 \mathrm{~nm}$. Crossing over of CD showed at $258 \mathrm{~nm}$.

Proline hydantoin showed an unique ORD curve. Molecular rotation enlarged graduately from $290 \mathrm{~nm}$ and the peak was at $253 \mathrm{~nm}$. Curve also showed the trough at $223 \mathrm{~nm}$ and crossed over about $245 \mathrm{~nm}$, and the peak showed about $214 \mathrm{~nm}$. It predicted that the asymmetric structure of proline showed the positive Cotton effect according to $\mathrm{C}-4$ carbonyl group.

Molecular rotations of hydantoins were 
not related with the side chains which were derived from amino acids. Molecular rotations of amino acid hydantoins, except serine hydantoins, were varied between 870 and 8,000 . Serine hydantoin indicated large molecular rotation $(10,000 \sim 12,000)$. It was interesting that serine hydantoin showed large

TABle IV. [ $\theta]$ of Hydantoins

\begin{tabular}{llll}
\hline & $\lambda_{\mathrm{min}}$ & & $\lambda_{\mathrm{mnx}}(\mathrm{nm})$ \\
\hline Ala $^{-}$ & $231(\mathrm{~nm})$ & -2610 & \\
Val & 232 & -8110 & \\
Leu & 231 & -5130 & \\
Ile & 234 & -5350 & \\
Asp* & 215 & -16900 & \\
Glu & 221 & -7570 & \\
Phe & 233 & -8990 & \\
Tyr* & 234 & -3810 & $207+1430$ \\
Try* & 241 & -4290 & $274+3550$ \\
Met & 236 & -3860 & \\
Ser & 232 & -20160 & \\
Thr* & 232 & -15050 & \\
Lys* & 212 & -9000 & \\
Arg* & 224 & -7910 & \\
His & Not measured & \\
Pro & 214 & - & $238+8300$ \\
\hline
\end{tabular}

molecular rotation in contrast to thiohydantoin which lost the optical activity by dehydration and formation of double bond or polymerization.

3. Absolute configuration of hydantoin-Application of "octant rule"-

Djerassi et al. ${ }^{4}$ ) reported that the positive Cotton effect of L-amino acid phenylthiohydantoin was attributable to $n \rightarrow \pi^{*}$ transition of thiocarbonyl group at $\mathrm{C}-2$. The positive Cotton effect could be expected for the carbonyl group at $\mathrm{C}-2$ of L-amino acid hydantoin. L-Amino acid hydantoin, however, gave the negative Cotton effect. The negative Cotton effect, therefore, was contributable to the carbonyl group at $\mathrm{C}-4$. In D-alanine hydantoin, ORD and $\mathrm{CD}$ curve showed symmetrically for L-alanine hydantoin.

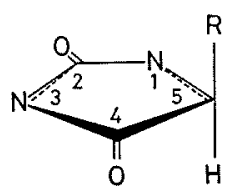

Table V. [M] OF Hydantoins

\begin{tabular}{lccccccc}
\hline & 350 & 300 & 280 & $260 \mathrm{~nm}$ & $\begin{array}{c}{[\mathrm{M}]_{\mathrm{min}}} \\
\mathrm{nm}\end{array}$ & $\begin{array}{c}\text { Cross } \\
\text { over } \\
\mathrm{nm}\end{array}$ \\
\hline Ala & -240 & -450 & -730 & -1600 & 244 & -3050 & 231 \\
Val & -600 & -1100 & -1640 & -3350 & 246 & -5480 & 232 \\
Leu & -400 & -690 & -990 & -1890 & 244 & -3480 & 226 \\
Ile & -460 & -860 & -1290 & -2520 & 246 & -4000 & 228 \\
Asp* & -630 & -1200 & -1640 & -2840 & 238 & -5990 & 215 \\
Glu & -590 & -1030 & -1520 & -2790 & 241 & -6030 & 221 \\
Phe & -840 & -1590 & -2410 & -4600 & 244 & -7920 & 220 \\
Met & -280 & -520 & -770 & -1640 & 245 & -2910 & 232 \\
Ser & -1230 & -2140 & -3320 & -6950 & 245 & -12350 & 231 \\
Thr* & -730 & -1380 & -1940 & -3230 & 245 & -5820 & 231 \\
Lys* & -510 & -930 & -1450 & -2380 & 240 & -5170 & 215 \\
Arg* & -460 & -850 & -1270 & -2340 & 240 & -5045 & 218 \\
His & -70 & -150 & -180 & -400 & 244 & -870 & - \\
\hline
\end{tabular}

Tyr* ; $350 \mathrm{~nm}(-460), 301(\mathrm{~min}-760), 290(-720), 272$ (cross over), $270(-210), 260(-330), 250$ $(-1340), 248(\min -1510), 240(-1240), 234$ (cross over), $230(+1340), 220(+3820), 218(\max$ $+4230), 210(+2060)$.

Try*; $350(-570), 344(\mathrm{~min}-590), 340(-510), 330(-450), 320(-390), 310(-280), 304$ (cross over), 275 (cross over), $256(-1060), 250(-1000), 240(-830)$.

Pro ; $350(-710), 300(-990), 290(-1030), 280(-940), 270(-420), 267$ (cross over), $260(+1360)$, $253(\max +3080), 245$ (cross over), $240(-3790) 223$ (min -).

*; $0.1 \mathrm{~mm}$ cell. Tyr, Try, Pro; wave length nm ([M]). 
In this way, "octant rule" may apply to these derivatives in a similar manner. This agreed with the absolute configuration of amino acids which are determined with $\mathrm{X}$-ray diffraction. $^{81}$

\section{REFERENCES}

1) A. Neuberger, Adv. in Protein Chem., IV, 297 (1948).

2) G. R. Stark, Biochem., 7, 1796 (1968).
3) W. R. Boon and W. Robson, Biochem. J., 29, 2573 (1935).

4) C. Djerassi, K. Undheim, R. C. Sheppard, W. G. Terry and B. Sjöberg, Acta Chem. Scand., 15, 903 (1961).

5) T. Suzuki and K. Tuzimura, in preparation.

6) R. E. Stuckey, J. Chem. Soc., 1947, 331.

7) M. Bovarnick and H.T. Clarke, J. Am. Chem. Soc., 60, 2426 (1938).

8) G. V. Gurskaya, "The Molecular Structure of Amino Acid," Consultants Breau, New York, 1968, p. 99. 